\title{
The Analysis of Alternative Distance Learning Implementation into the System of General Professional Training of Teachers
}

\author{
Nataliia N. Medynska ${ }^{1}$, Nataliia M. Sovtys ${ }^{2}$, Mykhailo Yu. Halatiuk ${ }^{3}$, Nataliia V. Symonovych ${ }^{4} \&$ Olena I. Shuryn ${ }^{5}$ \\ ${ }^{1}$ Department of the Ukrainian Language and Literature, Stepan Demianchuk International University of Economics \\ and Humanities, Rivne, Ukraine \\ ${ }^{2}$ Department of Ukrainian Language, Faculty of Ukrainian Philology, Rivne State University of Humanities, Rivne, \\ Ukraine \\ ${ }^{3}$ Department of Pedagogy, Education Management and Social Work, Faculty of Psychology and Natural Sciences, \\ Rivne State University of Humanities, Rivne, Ukraine \\ ${ }^{4}$ Department of Technological Education, Faculty Physics and Technology, Rivne State University of Humanities, \\ Rivne, Ukraine \\ ${ }^{5}$ Department of Theory and Methods of Professional Education, Faculty of Physics and Technology, Rivne State \\ University of Humanities, Rivne, Ukraine \\ Correspondence: Nataliia N. Medynska, Stepan Demianchuk International University of Economics and Humanities, \\ 4, Stepana Bandery str., Rivne, 33017, Ukraine.
}

Received: July 2, 2020

doi:10.5430/ijhe.v9n4p339
Accepted: July 20, 2020

Online Published: July 23, 2020

URL: https://doi.org/10.5430/ijhe.v9n4p339

\begin{abstract}
The purpose of the study was to justify and check experimentally the efficiency in the application of distance learning technologies to ensure future teachers' readiness to pedagogical work in the process of general professional training. The quasi-experimental research was conducted while delivering the disciplines of "Pedagogics" and "Psychology" included in the cycle of general professional training. The levels of motivational, activity-oriented, and cognitive components of future teachers' readiness to pedagogical work were measured using the determination methodology for the factors of the profession's attractiveness developed by Yadov, the questionnaire entitled "The identifier of problematic dominant level in the process of addressing pedagogical tasks", and the results of the final tests. To analyse the results obtained and to study objectively dynamics of changes in activity orientated, cognitive, and motivational elements, the research has used methods of mathematical data processing and a STATISTICA software for statistical analysis. The research found the efficiency of distance courses implementation with active teaching methods on the development of all components of future teachers' readiness to pedagogical work. The author concluded that in the context of the general professional training of teachers and adaptation to the peculiarities of distance learning, the most efficient methods are the following: case-study, a problem-oriented lecture, a method of projects, portfolio, and discussion. In the view of the author, distance educational technologies, means of virtual visualisation and interactive content help broaden the didactical potential of active methods of pedagogical interaction and diversify delivery of the training material.
\end{abstract}

Keywords: distance learning, distance courses, active training methods, future teachers, professional training

\section{Introduction}

Due to scientific and technological progress, reorientation of humanist values, changes in educational tendencies in the organisation and accessibility of education of various forms and levels are happening in the world. The Internet has provided new opportunities, forms, and means of education. In particular, a new notion of "distance learning" has appeared. Distance education or distance learning is an educational sphere concentrated on pedagogy, technologies, and educational systems directed towards obtaining a degree by students who cannot physically be in place (UNESCO, 2010). Now new terms are appearing: online education, digital education, electronic education, and virtual education, which represent synonymous and interchangeable notions determining the mechanism of distance learning transfer (Traxler, 2018). All these definitions addressing distance learning have three common features: flexibility, economy, and the person-orientation (Onyemaechi, 2013). 
Although distance learning is actively used in various countries, teachers-practitioners and scientists still have two drastically different ways of its implementation. The issue of distance learning quality remains problematic. Researchers (Markova et al., 2017) identified that in general, students positively assess their experience of distance learning. However, a lack of feedback or contact with a teacher worsens the training efficiency. The research results show that students who are studying distantly have worse results than full-time students (Lane \& Gregson, 2019). The first-year students have a significantly lower level of academic success in comparison with full-time students (Fojtík, 2018).

Besides the quality of education, in the practice of distance learning implementation, the following problems exist:

- on the part of students: a lack of feedback or contact with a teacher and the deficit of control (Pant, 2014); a lack of persistent motivation and the ability to work efficiently with the time, and the feeling of isolation (Fojtík, 2018);

- on the part of organizational moments: incorrect information and incorrect understanding of distance learning (Levy, 2007); a lack of technical support (Fojtík, 2018);

- on the part of teachers: usage of the identical pedagogical and teaching practice applied during the full-time study (Fojtík, 2018).

Distance learning helps solve essential social problems: it gives people of different age possibilities to get an education, which they did not get in the past; to master new competencies and the qualification for the future. The example of effective implementation of distance learning for solving these social problems can be Nigeria that eliminated the imbalance between the necessity in preparation of mass qualified teachers for secondary school and available funds (Ndayambaje et al., 2015) and Pakistan where distance learning has been accepted as an alternative educational system for the disadvantaged population group and working people to increase their educational opportunities (Arain \& Munshi, 2017). The coronavirus COVID-19 pandemic and quarantine measures implementation also challenged the educational system. In particular, in China, a wide-ranging program of online education was developed (Zhou et al., 2020).

Followers of distance learning (Allen et al., 2004; Shachar \& Neumann, 2003; Chivu, et al., 2018) claim that learning can be efficient in the same way or even more efficient than individual training courses. They state that a teacher unlikely can influence sufficiently on learning outcomes, though the content of training material, training methods, communication, and support of the students are highly important for students and can have an impact on its efficiency.

Thus, the increase of social necessity to implement and use distance learning, modern educational tendencies, social challenges, and current problems of distance education cause the necessity to study the experience of alternative distance learning implementation. In addition, what makes this research topical is that the analysis of distance learning efficiency in the system of general professional training of teachers is still explored insufficiently.

The research aims to justify and check experimentally the efficiency in the application of distance learning technologies to ensure future teachers' readiness to pedagogical work in the process of general professional training.

Based both on the topicality of the study and problems of distance learning, the main points of our research are:

1. Are the results of traditional and distance learning technology the same?

2. How does distance learning affect the students' readiness to carry out pedagogical work?

3. What methods can help increase the quality of distance learning?

\section{Methods and Materials}

The subjects of the research were the second-year students aged 19-20 seeking the degree in the specialty of "Secondary Education", ref. \#014. Two hundred and ninety university students were the population for the experimental work in the research. The size of the valid sample contained 117 people after calculating the size of a necessary (representative) sampling by using an online calculator (parameters: confidence interval $=95 \%$, an error margin $=7 \%)$. This quantity was initial for creating the experimental group $(\mathrm{EG})(\mathrm{n}=56)$ and the control group $(\mathrm{CG})$ $(\mathrm{n}=61)$.

The sampled groups were considered mutually homogeneous for the reason that the students obtained education in the same specialism (Levy \& Lemeshow, 2011).

The quasi-experimental research was conducted while delivering the disciplines of "Pedagogics" and "Psychology" included in the cycle of general professional training. Graduate students of the experimental group mastered the disciplines stated above through distance technologies in Moodle; students of the control group studied them 
traditionally. The research organisation included three stages during 2018-2019.

The research aims to justify and check experimentally the efficiency in the application of distance learning technologies to ensure future teachers' readiness to pedagogical work in the process of general professional training.

The first stage (preparatory) included:

- the selection, justification and theoretical understanding of the problem and the topic of the research;

- development of the program and methodology for the experiment;

- development of distance courses for disciplines of "Pedagogics" and "Psychology" by using active training methods.

The second stage (main) included:

- making pre-experimental measurement;

- the realisation of the experiment through distance courses for disciplines of "Pedagogics" and "Psychology";

- post-experimental calculations.

The third stage (final) included:

- pre-experimental and post-experimental data processing;

- interpretation of statistical rates;

- comparison of results obtained and expected;

- development of recommendations and presentation of the research results.

Based on the tasks of each stage, the author has used methods of analysis and synthesis of philosophical, psychological and pedagogical sources in the sphere of professional training of a future teacher; modelling and projecting to define theoretical and methodological means of the research; study and generalisation of the pedagogical experience in the development of distance courses; comparison and classification to identify the essential features, criteria, and levels of future teachers' readiness to pedagogical work; pedagogical experiment with quantitative and qualitative analysis of the results, namely Pearson statistical criterion $\left(\mathrm{x}^{2}\right)$. To analyse quantified data, a program package for statistical analysis entitled STATISTICA has been used.

In the first stage, having examined programs of disciplines included in general professional training in "Pedagogics" and "Psychology", we defined the program's competencies and results of the study, which students must obtain after their training. In the future, they will be regarded as materials to determine criteria and rates of future teachers' readiness for pedagogical work.

The components of future teachers' readiness to pedagogical work in terms of distance learning are motivational, cognitive, and activity-oriented, and they correlate with the criteria. According to these criteria, rates and three levels of future teachers' readiness to pedagogical work have been determined, namely: high, middle, and low (see Table 1).

Table 1. Criteria and rates to determine the levels of future teachers' readiness to pedagogical work

\begin{tabular}{|c|c|c|c|}
\hline Criterion & Motivational & Activity-oriented & Cognitive \\
\hline High level & $\begin{array}{l}\text { Positive attitude towards the } \\
\text { chosen profession, the high } \\
\text { level of motivation for the } \\
\text { pedagogical work. }\end{array}$ & $\begin{array}{l}\text { A student can accomplish } \\
\text { professional tasks and } \\
\text { address situations of an equal } \\
\text { level of complexity. }\end{array}$ & $\begin{array}{l}\text { The high level of discipline } \\
\text { knowledge (A grade } \\
\text { "excellent" according to the } \\
\text { ECTS scale). }\end{array}$ \\
\hline Middle level & $\begin{array}{l}\text { Neutral attitude towards the } \\
\text { chosen profession, the } \\
\text { average level of motivation } \\
\text { for the pedagogical work. }\end{array}$ & $\begin{array}{l}\text { A student can accomplish } \\
\text { professional tasks and } \\
\text { address situations of an } \\
\text { average and low level of } \\
\text { complexity. }\end{array}$ & $\begin{array}{l}\text { A sufficient level of } \\
\text { discipline knowledge (B } \\
\text { "very good" and C "good" } \\
\text { grades according to the } \\
\text { ECTS scale). }\end{array}$ \\
\hline Low level & $\begin{array}{l}\text { Mostly negative attitude } \\
\text { towards the chosen } \\
\text { profession, the low level of } \\
\text { motivation for the } \\
\text { pedagogical work. }\end{array}$ & $\begin{array}{l}\text { A student has problems with } \\
\text { both } \\
\text { professional } \\
\text { accomplishing } \\
\text { addressing } \\
\text { situations. }\end{array}$ & $\begin{array}{l}\text { A satisfactory level of } \\
\text { discipline knowledge (D } \\
\text { "satisfactory" and E } \\
\text { "sufficient" according to the } \\
\text { ECTS scale). }\end{array}$ \\
\hline
\end{tabular}


To identify the formation levels of motivational, activity-oriented, and cognitive components of future teachers' readiness to pedagogical work, the research has used various diagnostic methodologies based on the structure of the researched phenomenon. Thus, the formation level of a motivational component was determined using the determination methodology for the factors of the profession's attractiveness developed by Yadov (modification of Rean (2016)); the formation level of an activity-oriented component - by using the questionnaire titled "The identifier of problematic dominant level in the process of addressing pedagogical tasks" (Kashapov, 2006). A cognitive component was determined based on the results of the final test during sessions.

At the preparatory stage, the important phase of the research was the development of distance courses for disciplines of "Pedagogics" and "Psychology" for future teachers' general professional training and the search for efficient training methods. According to scientists (Pogodaeva et al., 2019; Fojtík, 2018) and studies on problems of distance technologies usage in China during prevention and control of the coronavirus COVID-19 epidemic (Zhou et al., 2020), typical distance courses built by analogy with the traditional education in classrooms are ineffective because students understand badly the knowledge gained and they also fail to use it in practice. The failure to obtain information directly from a teacher and the increase of self-reliance in the process of discipline mastering decrease the performance of the educational process (Rumble, 2019; Leontyeva, 2018). Nowadays to increase the quality of the educational process, scientists and practitioners are using innovative pedagogical methods. We are highlighting active training methods among them. They help master thoroughly practical professional skills and they can be adapted to the distance-learning environment. Main advantages of active training methods are students' activation during the learning process; motivation increase in mastering professional competencies; a partnership style of cooperation with all participants of learning; students' activity in the process of the search for new useful information; development of critical thinking and creative abilities (Riley \& Ward, 2017; Zayapragassarazan \& Kumar, 2012; Brame, 2016). However, modern studies (Borisova et al., 2016) point to the fact that active training methods are rarely used in the education of students while distance learning. The courses were designed to comply with the structure presented below (see Fig 1).

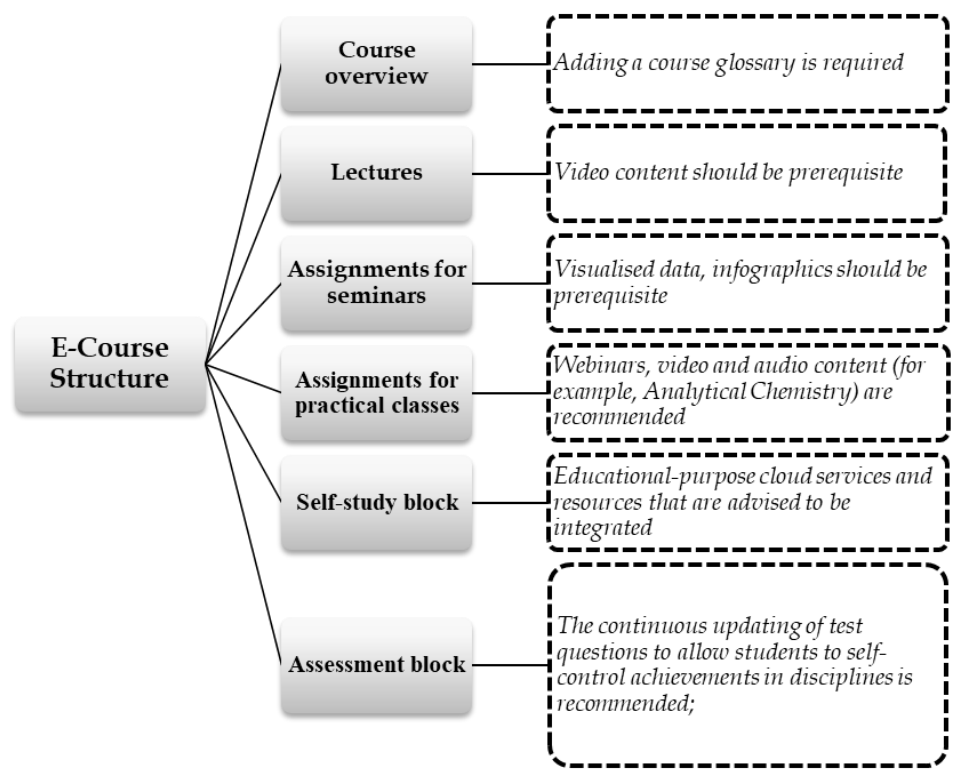

Figure 1. The distance course structure

Thus, we hypothesised that the formation of future teachers' readiness for pedagogical work would be more efficient if distance courses in "Pedagogics" and "Psychology" are developed with the usage of active training methods.

The literature on pedagogy has many classifications of innovation technologies. We used the classification of active methods suggested by Smolkin (1991). All methods of active training are divided into non-simulation (problematic lectures, lectures with the programmed mistakes, lectures-conferences, heuristic talks, seminars, educational discussions, individual work with the literature) and simulation, which include two groups: games (a business game, a role-play, a training, pedagogical situations, and pedagogical tasks) and not games (the analysis of particular situations, collaborative thinking activity). Nevertheless, not all methods listed above can be adapted to distance learning. 
To determine which methods are the most efficient and should be used, we distinguished the potential of active training methods to create future teachers' readiness for pedagogical work based on scientific and methodological literature (Table 2).

Table 2. The didactic potential of active training methods in the system of distance education

\begin{tabular}{|c|c|c|}
\hline Method & Advantages of application in distance learning & Uses in a distance course \\
\hline Case study & $\begin{array}{l}\text { Help unite directly theoretical material of the discipline } \\
\text { with practical tasks and master implementation of } \\
\text { knowledge obtained in the practice. It contributes to } \\
\text { active cooperation among all participants of the } \\
\text { educational process (a tutor, a course developer, and a } \\
\text { listener). It helps make the study professionally oriented } \\
\text { and practice on future professional problems and possible } \\
\text { tasks. }\end{array}$ & $\begin{array}{l}\text { Cases adaptation in the form } \\
\text { of problematic forums; } \\
\text { introduction of a case as a } \\
\text { "week task" with the } \\
\text { discussion. }\end{array}$ \\
\hline $\begin{array}{l}\text { Problematic } \\
\text { lecture }\end{array}$ & $\begin{array}{l}\text { Contribute to the interest in problems, phenomena, and } \\
\text { contradictions. Increase the desire to find the truth, and it } \\
\text { activates the motivational part of education. Prepare } \\
\text { future teachers to obtain knowledge individually. } \\
\text { Influence positively on the development of deep analysis } \\
\text { skills, funding of the information core, see a problem, and } \\
\text { find correct solutions. }\end{array}$ & $\begin{array}{l}\text { Possibility to deliver a lecture } \\
\text { in the mode of a } \\
\text { teleconference, a webinar } \\
\text { with the discussion in a chat } \\
\text { (or video recording of the } \\
\text { lecture with the discussion in } \\
\text { a forum). }\end{array}$ \\
\hline $\begin{array}{l}\text { Projects } \\
\text { method }\end{array}$ & $\begin{array}{l}\text { Project technology improves skills of individual or group } \\
\text { work, the ability to work on yourself, use rationally time, } \\
\text { and plan one's activity. Help study the topic or problem } \\
\text { given deeper and use one's creative abilities. }\end{array}$ & $\begin{array}{l}\text { Possibility to create } \\
\text { electronically a project or } \\
\text { portfolio with the usage of } \\
\text { various online services. }\end{array}$ \\
\hline Portfolio & $\begin{array}{l}\text { Include the accumulation of works set within the } \\
\text { educational process. Help monitor the professional growth } \\
\text { of a student and his/her learning outcomes. This method } \\
\text { can be used as a "methodological treasury" for future } \\
\text { teachers. }\end{array}$ & $\begin{array}{l}\text { Students can send tasks to the } \\
\text { teacher's e-mail, electronic } \\
\text { disks, university repository, } \\
\text { educational services, and so } \\
\text { on. }\end{array}$ \\
\hline Discussion & $\begin{array}{l}\text { Allow cooperate with all discussion participants during } \\
\text { the process of communication, contribute to the skills to } \\
\text { express an opinion and argue, debate on the professional } \\
\text { topics, absorb the professional culture and } \\
\text { communication. Discussion allows taking productive }\end{array}$ & $\begin{array}{l}\text { Can be demonstrated in } \\
\text { real-time in a chat, in an } \\
\text { Internet teleconference or } \\
\text { Internet r telephone } \\
\text { conference. }\end{array}$ \\
\hline
\end{tabular}
decisions of a group task.

Thus, didactical potential specified in the research and possibilities of technical implementation made it possible to develop distance courses in "Pedagogics" and "Psychology" for future teachers. To familiarise students with peculiarities of a distance course and to provide methodological recommendations, a methodological seminar was held. The essential part of our experiment was to consult permanently students by emails, in social nets, and on the platform Moodle. In addition, future teachers took part in skype-conferences, got additional rating points for completing public online courses on their specialty.

The next task of our research was to make pre-experimental measurements. To check the efficiency of the stated methodology, it was necessary to determine initial formation levels of components' readiness to the students' pedagogical work based on the questionnaire and testing stated in the methodological base. The data received during this diagnostic process are presented in Table 3. 
Table 3. A comparative table of future teachers' readiness to pedagogical work (pre-experimental measurements)

\begin{tabular}{llll}
\hline Criteria & Levels & \multicolumn{2}{l}{ Pre-experimental measures (\%) } \\
& & EG & CG \\
\hline Motivational & High & 19.1 & 21.9 \\
& Middle & 55.3 & 53.2 \\
\multirow{3}{*}{ Activity-oriented } & Low & 25.6 & 24.9 \\
& High & 22.1 & 19.1 \\
& Middle & 54.8 & 56.1 \\
Cognitive & Low & 23.1 & 24.8 \\
& High & 24.2 & 24.9 \\
& Middle & 58.9 & 57.1 \\
& Low & 16.9 & 18 \\
\hline
\end{tabular}

According to the data above, before experimenting with the EG and CG are generally similar to the main rates of future teachers' readiness to pedagogical work. Based on rates of the motivational component of readiness to pedagogical work the majority of the students demonstrated the middle level $(55.3 \%$ and $53.2 \%) .25 .6 \%$ of the students of the experimental group and $24.9 \%$ of those in the control group have a low level. Rates of the high level of a motivational component prove that these groups are almost the same: $19.1 \%$ of respondents in the experimental group and $21.9 \%$ in the control one.

Based on the criteria of the activity-oriented component of readiness to pedagogical work development students with the middle level (54.8\% and 56.1\%) constituted the biggest part both in the experimental and control groups. $22.1 \%$ of future teachers in the experimental group and $19.1 \%$ in the control group have a high level of activity-oriented component development. Almost the same quantity of participants $(23.1 \%$ in the experimental group and $24.8 \%$ in the control group) demonstrated the low level of readiness formation to pedagogical work based on the component described.

In accordance with the rates of the cognitive component of readiness to pedagogical work in both groups, $25 \%$ of the students-interviewees belong to the high level. The largest part - 58\% in the experimental group and $57.1 \%$ in the control group - belongs to the students with the middle formation level of the feature stated above. The low level of the component formation was indicated in $16.9 \%$ of the students in the EG and $18.0 \%$ of the students in the CG.

As can be concluded from the data above, both groups are practically the same in terms of division; the students have mostly the middle readiness level to pedagogical work. Less than a quarter of the interviewees are characterised by a high level.

\section{Results}

Based on the same diagnostic elements, the repeated measurements were made after implementation distance courses "Pedagogics" and "Psychology" into the educational process. Their results are presented in Table 4.

Table 4. A comparative table of future teachers' readiness to pedagogical work (post-experimental measurements)

\begin{tabular}{llll}
\hline \multirow{2}{*}{ Criteria } & Levels & \multicolumn{2}{l}{ Post-experimental measures (\%) } \\
& & EG & CG \\
\hline \multirow{3}{*}{ Motivational } & High & 30.8 & 23.8 \\
& Middle & 57.9 & 53.5 \\
& Low & 11.3 & 22.7 \\
\multirow{3}{*}{ Activity-oriented } & High & 33.8 & 19.5 \\
& Middle & 56.9 & 57.6 \\
& Low & 9.3 & 22.9 \\
\multirow{3}{*}{ Cognitive } & High & 40 & 25.9 \\
& Middle & 53.8 & 62.4 \\
& Low & 6.2 & 14.9 \\
\hline
\end{tabular}


The comparison of rates in Table 4 shows positive changes in all components of future teachers' readiness to pedagogical work in experimental and control groups. The following changes in the motivational component of future teachers' readiness in the experimental group occurred: the number of low-level students decreased by $14.3 \%$, the number of high-level students increased by $11.7 \%$, and the number of middle-level students increased by $2.6 \%$. Positive changes also occurred in the control group, though they are not so significant: the number of low-level students decreased by $2.2 \%$, the number of high-level students increased by $1.9 \%$, and $53.5 \%$ of the students are characterised by the rates of the middle level (the difference between pre-experimental and post-experimental measurements is $0.3 \%$ ).

The best rates are observed in the cognitive component. Therefore, in the experimental group rates of the high formation-level increased by $15.1 \%$, those of the middle one decreased by $5.1 \%$, and those of the low level decreased by $3.1 \%$.

The analysis of formation rates of the activity-oriented component of future teachers' readiness to pedagogical work in the experimental group demonstrates the growth of high-level rates by $11.7 \%$, the growth of middle-level - by $2.1 \%$, and low-level rates decreased by $13.8 \%$ accordingly. At the same time, in the control group changes in high-level rates increased by $0.4 \%$, in middle-level ones by $1.5 \%$, and the low-level rates decreased by $1.9 \%$.

In general, changes in the CG occurred but they are not so significant.

Application of distance courses along with the usage of active training methods in "Pedagogy" and "Psychology" has become the reason for the increase in rates of high-level readiness to pedagogical work and transfer of the low-level students to a middle-level group in the experimental group.

To identify if there is any difference in students' allocation by levels of readiness to a pedagogical work in the EG and $\mathrm{CG}$ after the experiment, we used the criterion $\mathrm{X}^{2}$.

Formulate the hypothesis:

$\mathrm{H}_{\mathrm{o}}$ - the readiness level to pedagogical work after the experiment is equal in both EG and CG;

$\mathrm{H}_{1}$ - the readiness level to pedagogical work after the experiment is higher in the experimental group than in the control one.

The value obtained $X^{2} E m p=21,68$ is higher than the critical one, which for the value $p=0.95$, and a number of degrees of freedom $C=2$ is equal to $X^{2}=5.991$. Thus, $21.68>5.991\left(X^{2} E m p>X^{2}\right)$ for $p=0.95$. As a result, the hypothesis $\mathrm{H}_{0}$ is denied, and the hypothesis $\mathrm{H}_{1}$ is accepted. The difference between allocation is statistically credible.

\subsection{Restrictions of the Research}

The main restrictive factors of the research are the fact that the experimental work was conducted only during studying disciplines of "Pedagogics" and "Psychology." The restriction factors also include a short period timeline for the realisation of the formational experimental stage (the first term).

\section{Discussion}

Below are the answers to the research questions. They are presented in the same order. First, experimental research has proved that the difference between education results based on traditional and distance technology exists. The distance courses developed have proved to be more effective in comparison with traditional education. We believe that it can be explained by the fact that the educational process became more individualised, a student did not hesitate to ask a teacher questions in electronic form or during a videoconference. The systematic support and monitoring of courses were also done. It helped students feel the teacher's control and not extend beyond the terms of materials learning. The students studied theoretical material individually and had an opportunity to get additional points for completing online courses on the specialty. The high rates of the cognitive component in the experimental group reflect the information stated above. Second, distance learning has a positive impact on the students' readiness for pedagogical work. The students who mastered the disciplines have higher rates of cognitive and activity-oriented components. The increase of cognitive component rates is explained by the fact that they studied the material individually, memorised more information, and used additional informational sources from the electronic library and the service of online courses. The impact on the activity-oriented component of readiness to pedagogical work was done through practically oriented active training methods: portfolio, case study, project method, and discussions. The peculiarity of these methods application in distance learning is that they are not directed towards common exercises. They help students think creatively, put the knowledge gained into practice, and imitated pedagogical situations. The motivational component increase remains a challenge. The measurement results of this component obtained below deal with the orientation of distance learning on external motivation (a motive to get marks) and not on inner 
motivation (acquiring professional competencies). Third, we should state that the implementation of active training methods has an impact on the increase in distance learning quality. Comparing the results of previous research (Mahlangu, 2018; Lane \& Gregson, 2019; Fojtík, 2018), we identified that traditional distance learning has a lower quality of the knowledge gained. The peculiarities of our methodology were that we specified the didactic potential and chose those active training methods, which ensure a practical component of future teachers' training to a greater extend. The important stage in distance courses development was the selection and adaptation of active training methods according to the complexity of materials and competencies that students had to master after a particular topic study.

\section{Conclusions}

Summing up, we can claim that the process of disciplines mastering with the application of a distance education system is efficient. The data of experimental research has proved the hypothesis stated in the research. Based on the analysis and results in the generalisation of the pedagogical experiment hold, the following conclusion can be made: realisation of the experimental program during the training of the student teachers has a number of advantages that help complete educational tasks efficiently.

Electronic distance learning allows students to obtain necessary knowledge individually by using the most appealing informational resources. Modern capacities of applications and new programs have allowed doing the learning process more intensive and exciting for a student. In this way, continuity and systematicity of individual work are reached. In addition, it helps increase the teacher's control efficiency because a graduate can experience necessary consultations and answers on questions promptly, submit completed tasks not losing the time on meetings with a teacher. The quality of educational material also increases.

Graduate students have an opportunity to work at a convenient time (mostly at home), that is why learning through the electronic system is distinguished by its independence, and the quality of students' knowledge relies on their self-organisation.

Development and implementation of electronic distance courses promote the increase of teacher's educational, methodological, and scientific work because the course management makes a developer review training material constantly along with improving and updating lectures and tests.

In their turn, active training methods can maximise the level of engagement of the students in the formation process of readiness to pedagogical work. Distance educational technologies enhance the didactical potential of the known active methods of pedagogic cooperation and diversify delivery of the training material. In addition, they enable students to learn the discipline effectively.

Summarising the information stated above, we are stressing that the development and design of distance courses with the usage of active training materials can only be done by certain teachers-innovators with the high level of creativity as the specificity of active training methods usage in distance learning is related not only to the specificity of these methods but also to the peculiarities of training and students' perception of them. Accordingly, it is useful to organise the specialism-related training for teachers on how to develop distance courses with the usage of active training methods.

Further research is needed in the automation of some domains of distance learning.

\section{References}

Allen, M., Mabry, E., Mattrey, M. \& Burrell, N. A. (2004). Evaluating the effectiveness of distance learning: A Comparison Using Meta-Analysis. Journal of Communication, 54(3), 402-420. https://doi.org/10.1111/j.1460-2466.2004.tb02636.x

Arain, S. S., \& Munshi, P. (2017). Problems of distance learners in Province of Sindh, Pakistan. Asian Journal of Social Sciences \& Humanities, 6(3), 139-147.

Borisova, O. V., Vasbieva, D. G., Malykh, N. I., Vasnev, S. A., \& Bírová, J. (2016). The problem of Using Innovative Teaching Methods for Distance Learning Students. International Electronic Journal of Mathematics Education, $11(5), 1175-1184$.

Brame, C. (2016). Active learning. Retrieved from https://cft.vanderbilt.edu/wp-content/uploads/sites/59/Active-Learning.pdf

Chivu, R.-G., Turlacu, L.-M., Stoica, I., Radu, A. V. (2018). Identifying the effectiveness of e-learning platforms among students using Eye-Tracking technology. 4th International Conference on Higher Education Advances 
(HEAd'18) Universitat Politecnica de Val 'encia. 621-628. http://doi.org/10.4995/HEAd18.2018.8046

Fojtík, R. (2018). Problems of distance education. International Journal of Information and Communication Technologies in Education, 7(1), 14-23. https://doi.org/10.2478/ijicte-2018-0002

Kashapov, M. (2006). Psychology of creative thinking of a professional: monograph. Moscow: PER.

Lane, A., \& Gregson, J. (2019). Fostering innovations in pedagogical practices: transforming distance education through a professional development programme using OERs. Retrieved from http://oasis.col.org/bitstream/handle/11599/3387/PCF9_Papers_paper_99.pdf?sequence=1\&isAllowed=y

Leontyeva, I. A. (2018). Modern distance learning technologies in higher education: introduction problems. Eurasia Journal of Mathematics, Science and Technology Education, 14(10), Article em1578. https://doi.org/10.29333/ejmste/92284

Levy, Y. (2007). Comparing dropouts and persistence in e-learning courses. Computer \& Education, 48(2). 185-204. https://doi.org/10.1016/j.compedu.2004.12.004.

Levy, P. S. \& Lemeshow, S. (2011). Two-Stage Cluster Sampling: Clusters Sampled with Equal Probability. In P. S. Levy \& S. Lemeshow, Sampling of Populations: Methods and Applications, Fourth Edition, 269-330. https://doi.org/10.1002/9780470374597.ch10

Mahlangu, V. P. (2018). The Good, the Bad, and the Ugly of Distance Learning in Higher Education. Chapter 2 in Trends in E-learning, 17-29. http://doi.org/10.5772/intechopen.75702

Markova, T., Glazkova, I., \& Zaborova, E. (2017). Quality issues of online distance learning. Procedia - Social and Behavioral Sciences, 237, 685-691. https://doi.org/10.1016/j.sbspro.2017.02.043

Ndayambaje, I., Bimenyimana, T., \& Ndahayo, V. (2015). A study on the practices and challenges of distance Training Programme (DTP) under Kigali Institute of Education (KIE). Rwandan Journal of Education, 1(2), 69-76.

Onyemaechi, J. O. (2013). Policies, and practices of open and distributed learning models in sub-Saharan African countries: A literature survey. American Journal of Contemporary Research, 3, 122-135.

Pant, A. (2014). Distance learning: history, problems, and solutions. Advances in Computer Science and Information Technology, 1(2), 65-70.

Pogodaeva, M. V., Mikhailova, E. K., \& Usheva, T. F. (2019). The use of a reflexive approach in distance education of students at teacher-training institutions. In Proceedings of the 2019 4th International Conference on Distance Education and Learning (ICDEL 2019), 1-5. New York: Association for Computing Machinery. https://doi.org/10.1145/3338147.3338148

Rean, A. (2016). Person's psychology. St-Peterburg: Piter.

Riley, J., \& Ward, K. (2017). Active learning, cooperative active learning, and passive learning methods in an accounting information systems course. Issues in Accounting Education, 32(2), 1-16. https://doi.org/10.2308/iace-51366

Rumble, G. (2019). The planning and management of distance education. New York: Routledge. https://doi.org/10.4324/9780429288661

Shachar, M., \& Newmann, Y. (2003). Differences between traditional and distance education academic performances: A meta-analytic approach. The International Review of Research in Open and Distributed Learning, 4(2). https://doi.org/10.19173/irrodl.v4i2.153

Smolkin, A. (1991). Active training methods. Moscow: Higher school.

Traxler, J. (2018). Distance learning - predictions and possibilities. Education Sciences, 8(1), 35. https://doi.org/10.3390/educsci8010035

UNESCO. (2010). Trends in Tertiary Education: Sub-Saharan Africa. Montreal: UNESCO.

Zayapragassarazan, Z., \& Kumar, S. (2012). Active Learning Methods. NTTC Bulletin, 19(1), 3-5.

Zhou, L., Wu, S., Zhou, M., \& Li, F. (2020). School's out, but the class' on', the largest online education in the world today: taking China's practical exploration during the COVID-19 epidemic prevention and control as an example. Best Evidence of Chinese Education, 4(2), 501-519. http://doi.org/10.2139/ssrn.3555520 